\title{
Chapter 3 \\ The Middle-Income Trap \\ in the ASEAN-4 Countries \\ from the Trade Structure Viewpoint
}

\author{
Satoru Kumagai
}

As described in the "East Asian Miracle" by the World Bank (1993), East Asian countries have successfully developed their economies over the last half century. Sometimes the sequential economic development process in East Asia is illustrated as the "flying geese" pattern (FGP; Akamatsu 1935, 1962; Kojima 2000) in which Japan is regarded as the leading goose in East Asia, followed by Asian newly industrialized economies (NIEs), the four leading members of the Association of South East Asian Nations (known as the ASEAN-4), China, and finally, the latecomer ASEAN countries.

However, skepticism over this catching-up process of economic development in East Asia had been spreading for the last decade, along with the concept of the "middle-income trap" (MIT). The fear of failed industrial upgrading, especially for ASEAN countries and China, is a key topic that attracts the attention of governments, international organizations, and academia against the backdrop of the trend of a reduced economic growth rate.

In this chapter, we investigate the issues of the MIT for the ASEAN-4 countries (Indonesia, Malaysia, Thailand, and the Philippines) from the viewpoint of the trade structure. If the ASEAN-4's changing trade structure is not following the precedent set by the front "geese" in Asia, namely Japan, Korea, and Taiwan, then we should be concerned about the MIT caused by the failed industrial upgrading of the region. In particular, the trade structure of the ASEAN-4 had followed Japan and Korea relatively well until the mid-1990s, but started to diverge from its predecessors in the 2000s. We will interpret the meaning of this diversion in the trade structure later in this chapter.

The chapter is structured as follows. In the first section, we summarize the arguments surrounding the MIT and check the historical record of economic development

\footnotetext{
S. Kumagai (凶)

Economic Geography Studies Group of Development Studies Center at the Institute of Developing Economies, Japan External Trade Organization, Chiba, Japan

e-mail: satoru_kumagai@ide.go.jp 
for the ASEAN-4. In Sect. 3.2, we relate the FGP with the trade structure by using the net export ratios (NXRs) for different product categories based on the United Nations' broad economic categories (BEC). In Sect. 3.3, we investigate the trade structure of the ASEAN-4 by the NXR and reveal that the industrial upgrading in the ASEAN-4 seems to have stalled after the year 2000. In Sect. 3.4, we discuss the reason why the industrial upgrading in ASEAN-4 has stalled, and propose two possible factors, namely a "resource curse" and the lack of homegrown multinational corporations (MNCs) in the manufacturing sector. Finally, we conclude the paper by summarizing the findings and propose some policy implications for the ASEAN-4 countries.

\subsection{Middle-Income Trap and the ASEAN-4}

\subsubsection{Arguments of MIT for East Asia}

Although the concept of the MIT, which is first proposed by Gill and Kharas (2007), has become popular among development agencies and policy makers in the last decade, the definition of the MIT is blurred and the theoretical foundation is rather weak. The common denominator of the MIT definitions is slowed economic growth in the middle-income level. However, the previous literature on the MIT for East Asia generally seems to share the viewpoint that "failed industrial upgrading" is or will be a major cause of the MIT for the countries in this region.

Kohli et al. (2011, p. 34) define the MIT as a situation in which middle-income countries are "unable to compete with low-income, low-wage economies in manufacturing exports and unable to compete with advanced economies in high skill innovations." This definition shares a common view on the cause of the MIT in East Asia, namely, failed industrial upgrading. There are plenty of studies that suggest the risk of the MIT for each ASEAN country. Yusuf and Nabeshima (2009) conducted a comprehensive analysis on the electronics sector in Penang, Malaysia, and concluded that weak industrial linkages and an insufficient innovation capacity possibly prevent the island state from upgrading and diversifying its economy. Ohno (2009) used the analogy of a "glass ceiling" to explain the MIT, suggesting that none of the ASEAN countries has broken through the glass ceiling between the stage in which a number of local SMEs have appeared, but still need foreign guidance, and the higher stage, in which local firms have mastered management and technology and can successfully produce high quality goods. Tran (2013) comprehensively discussed the MIT for ASEAN countries, comparing them against Korea, and recommends the enhancement of R\&D capability and productivity for advanced ASEAN members to avoid the MIT. 


\subsubsection{How Slow Is the Rate of the Trap Threshold?}

One of the difficulties in defining the MIT is to determine how slow the growth must be to be called a "trap." For instance, Felipe (2012) defined the MIT as passing through the middle-income category at a less-than-average speed. The author first defined four income categories: low income (1,990 per capita PPP below $\$ 2,000)$, lowermiddle (between $\$ 2,000$ and $\$ 7,250$ ), upper-middle (between $\$ 7,250$ and $\$ 11,750$ ) and high income (above \$11,750). Then, using data from 1950 to 2010 for 124 countries, the author determined that the average number of years taken to graduate from the lower-middle income category to the upper-middle income category was 28 years; from the higher-middle income to the high-income category was about 14 years. Based on this analysis, among the ASEAN-4, as of 2010, Malaysia and the Philippines have been in a middle-income trap.

The definition by Felipe (2012) suggested a way to analyze the MIT with a clear criterion, but has some weakness. For instance, a country with no growth at all for a decade and a country with a growth rate just below the average growth rate of very successful countries, such as Japan, Korea, or European nations, are both classified as a "trapped" country under this definition.

In contrast, Aiyar et al. (2013) defined the MIT as sudden and sustained deviations from the ordinary growth path predicted by a standard conditional convergence framework. They improved the methodology of Eichengreen et al. (2012) to capture economic slowdown in broader income levels and analyzed the data for 138 countries over 11 five-year periods (1960-2005) to identify trapped countries and the relevant time periods. They detected 123 slowdown episodes out of 1,125 observations, and they include Malaysia in 1980-1985 and 1995-2000, Thailand in 1995-2000 and Indonesia in 1995-2000 as slowed down episodes.

Aiyar et al.'s (2013) definition is reasonable from the viewpoint of growth theory. However, it is not perfect because, with this definition, it is impossible to distinguish a sharp decline in growth rate caused by a temporary shock, such as the Asian financial crisis in 1997-98, from a prolonged slowdown caused by structural problems.

\subsubsection{Historical Growth of the ASEAN-4}

Figure 3.1 shows the historical record of the GDP per capita in nominal USD for the ASEAN-4 countries. The dotted line is the threshold between four income categories set by the World Bank, namely, low income, lower-middle income, uppermiddle income, and high income, which varies year by year. It is obvious that the Asian financial crisis in 1997-1998 affected the ASEAN-4, except for the Philippines, preventing these countries from climbing to a higher income category. The 2000s, however, was a good decade for ASEAN-4 countries because they stably increased their GDP per capita in nominal USD during that timeframe. Malaysia approached the top of the upper-middle income threshold and Thailand crossed the 


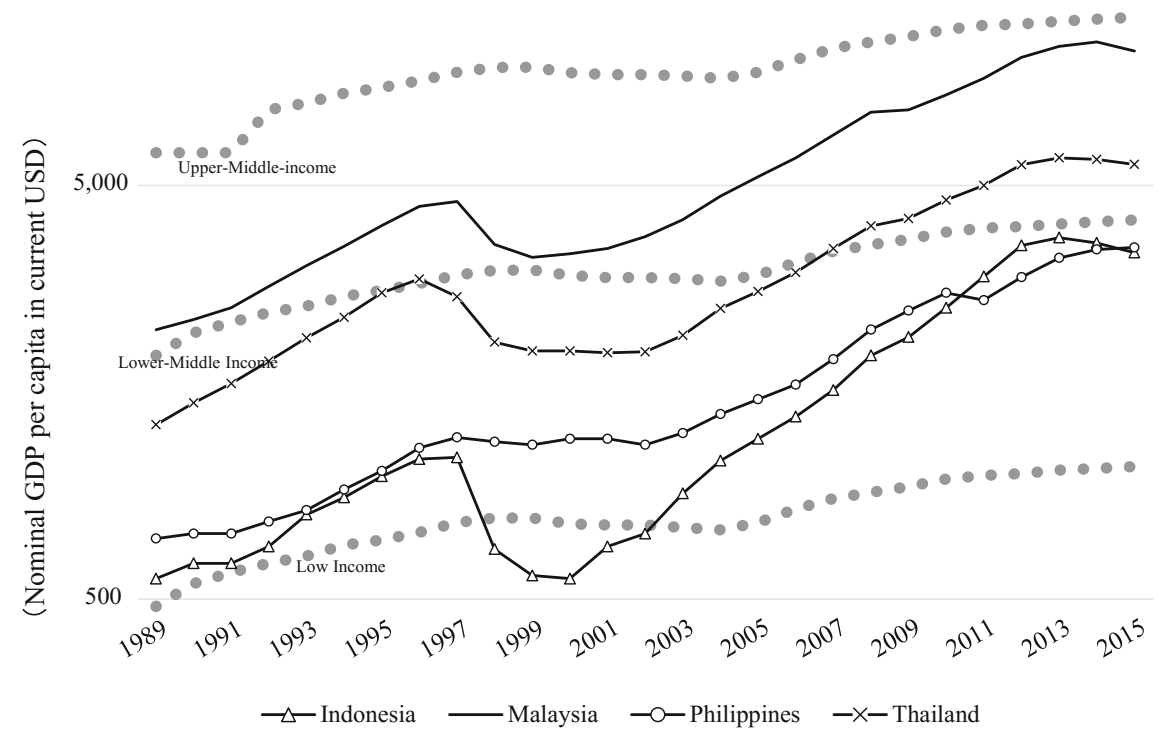

Fig. 3.1 GDP per capita for ASEAN-4 countries and income thresholds, 1989-2015. Source Drawn by the author based on World Development Indicators online data

border between lower-middle income to the upper-middle income category in 2007. Indonesia recovered rapidly from the Asian financial crisis and approached the top of the lower-middle income category. The Philippines grew steadily during the decade, approaching the top of the lower-middle income category.

In the 2010s, we observe a slowdown in the growth rate in GDP per capita in nominal USD for the ASEAN-4 countries. It appears that Malaysia has been struggling to cross the border into the upper-middle income category and Indonesia and the Philippines are struggling to cross into the lower-middle income category. Thailand is also stuck in the lower half of the upper-middle income stage. This slowdown is a backdrop for the growing fear of the MIT for the ASEAN-4 countries.

Figure 3.2 shows the average growth rate of real GDP in local currencies for Japan, the Asian NIEs (Hong Kong, Korea, Taiwan and Singapore), the ASEAN-4, China, and the group of countries known as CLMV (Cambodia, Lao PDR, Myanmar and Vietnam) for each decade. Japan, which had led the economic growth in East Asia, lost its growth momentum after the 1990s. The Asia NIEs, as a group, had a high recorded growth rate, but it gradually slowed to $3 \%$ per annum in the 2010 s. China and CLMV had high growth in the 1990s and the 2000s, but seem to be slowing down in the 2010s, although the average annual growth rate is still above $7 \%$. Compared with the other groups of countries, the average growth rate of the ASEAN-4 has been stable. After the high growth era of the 1960s and the 1970s, their GDP growth rates have all been hovering around $5 \%$ per annum until today.

Figure 3.3 shows the average annual growth rate of real GDP in local currencies by decade for each ASEAN-4 country. The 1970s was a decade of high-growth 


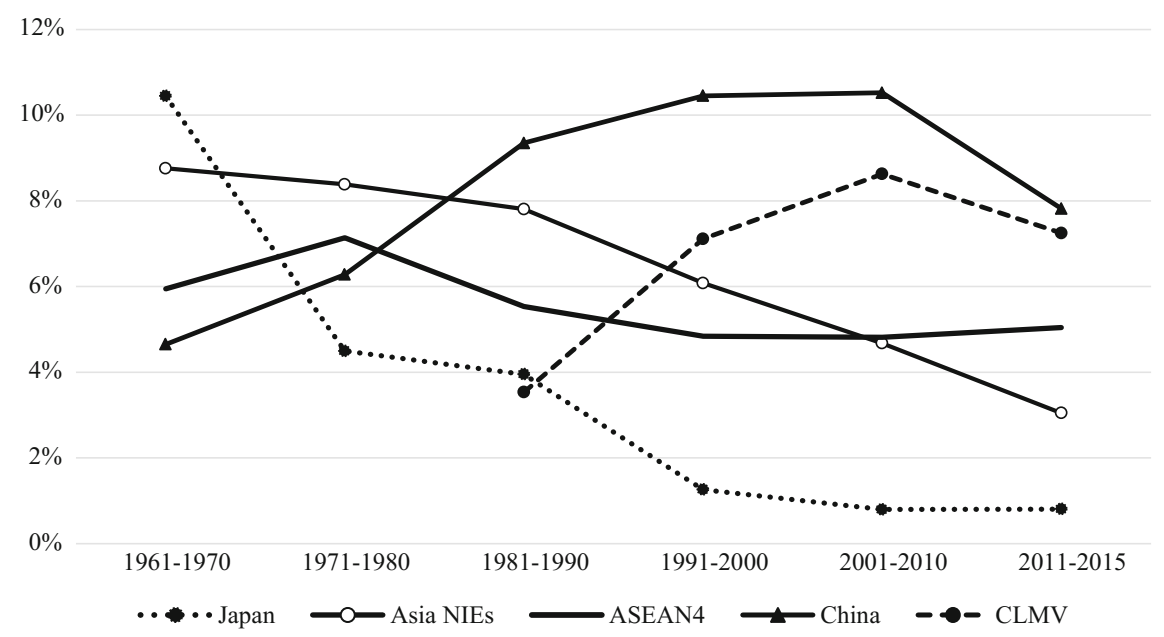

Fig. 3.2 Average GDP growth rates by decade, 1961-2015. Source Drawn by the author based on World Development Indicators online data

for the ASEAN-4 with the Philippines showing the lowest growth rate at 5.9\% per annum and the other four countries all over 7\%. The 1980s was a lost decade for the Philippines with a growth rate of only $1.8 \%$ per annum, while the other three countries recorded another decade of relatively high growth. In the 1990s, the ASEAN-4 countries, except for the Philippines, were severely affected by the Asian financial crisis in 1997-1998. Still, in that decade, Malaysia had an average growth of 7.2\% and Thailand and Indonesia experienced 4.6 and $4.4 \%$ growth per annum, respectively. In the 2000s, all of the ASEAN-4 countries grew at around 5\% per annum for the decade. In the 2010s, Indonesia and the Philippines have accelerated their economic growth to around $6 \%$ per annum, Malaysia's growth rate has been stable at around 5\%, and Thailand has been experiencing a decline of its economic growth to below $3 \%$.

All in all, there is no tendency of sudden slowdown of the economic growth for the ASEAN-4 in terms of GDP in local currency, except for Thailand in the 2010s. Indeed, the Philippines and Indonesia have accelerated their economic growth. Still, the stagnant per capita GNI growth rate in terms of nominal USD fosters the "fear" of a MIT, not an actual MIT. The stagnation seems more relevant to the recent depreciation of Asian currencies against the USD, including the Japanese Yen and Chinese Yuan. Only for Thailand does the MIT seem to be a real threat; however, it is not very clear whether the slowdown is caused by economic factors or by the political instability and floods in that country in 2011 and 2013. 


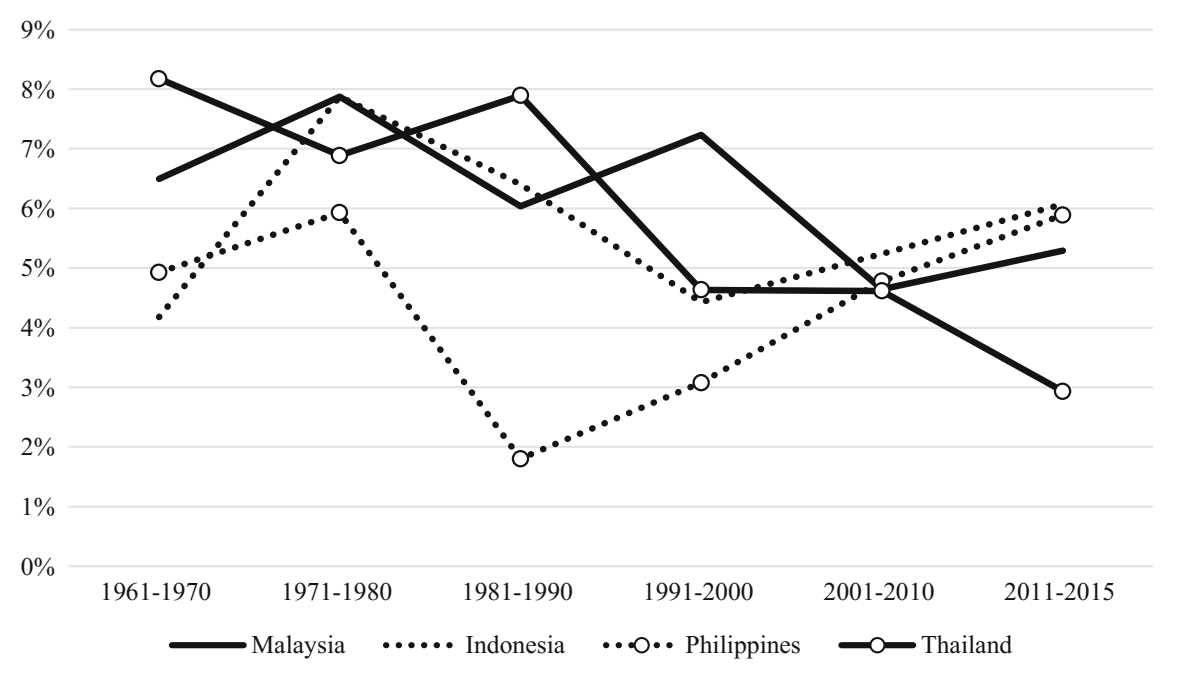

Fig. 3.3 Average GDP growth rates by decade for ASEAN-4 countries, 1961-2015. Source Drawn by the author based on World Development Indicators online data

\subsection{The Flying Geese Pattern from the NXR}

\subsubsection{Explanation of the FGP}

If one subscribes to the "failed industrial upgrading" view of the MIT, the FGP of economic development is worthy of exploration. Economic development in East Asia has been characterized by the sequential "take-off" of member countries, often termed the FGP of economic development. Actually, the FGP is applicable both to the sequential development of different industries within a country and the sequential development of countries internationally. If a country does not follow the FGP of economic development, then we suspect that the country is failing in the process of industrial upgrading and may be in a MIT.

The FGP supposes that a country's exports usually start with consumption goods, followed by parts and components and capital goods. This recognition is clear in Akamatsu $(1935,1962)$, from whence the FGP was initially postulated. Akamatsu explained the fundamental pattern of the FGP through the following four stages:

Stage 1: Import of manufactured consumer goods begins.

Stage 2: Domestic industry begins production of previously imported manufactured consumer goods while importing capital goods to manufacture those consumer goods.

Stage 3: Domestic industry begins exporting manufactured consumer goods. 
Stage 4: The consumer goods industry catches up with similar industries in developed countries. Export of consumer goods begins to decline, and the capital goods used for production of the consumer goods are exported.

Kojima (1960) attempted to explain that the accumulation of capital (i.e., the Heckscher-Ohlin factor) is the fundamental driving force of the FGP. Kojima (2000) also mentioned that other driving forces are the Ricardian advantage of learning-bydoing and economies of scale.

\subsubsection{FGP in Trade Structure}

There are several ways to depict the characteristics of trade patterns for a country. Proper measures are needed to investigate a country's trade structure in conjunction with the FGP. The revealed comparative advantage (RCA) index is often used in trade analyses. For instance, Dowlinga and Cheang (2000) showed how the export structure of Asian NIEs shifted from 1975 to 1985, while that of the ASEAN-4 shifted more rapidly between 1985 and 1995, according to analysis using the RCA in conjunction with FDI. Ginzburg and Simonazzi (2005) also used the RCA at the SITC 3-digit level to show that the FGP is still a relevant way to explain the trade structure in the electronics industry in East Asia.

However, a large exporter of one good may also be a much larger importer of the same good. In this case, the RCA cannot properly detect the comparative advantage for a country. Here the NXR is another index to be considered. It is theoretically more valid in the context of trade analysis and allows for an empirical illustration of the competitive advantages of each country. The NXR is calculated as follows.

$$
N X R_{c i}=\left(X_{c i}-M_{c i}\right) /\left(X_{c i}+M_{c i}\right)
$$

where $X_{c i}$ is the export of goods $i$ from country $c$, while $M_{c i}$ is the import of the goods $i$ for country $c$. Basically, if the NXR is more than 0 , it means that country $c$ has relative strength in exporting goods $i$. The NXR is also known as a theoretically sound index to investigate trade structure because it is highly correlated with the concept of the factor content of trade (Deardorff 1982).

Moreover, the NXR is an intuitive method to illustrate the changing trade structure along the FGP with Akamatsu's four stages (Fig. 3.4). The vertical axis is the NXR of consumer goods (solid line) and capital goods (dotted line). By utilizing the NXRs for two types of goods, we can visually illustrate the four stages of FGP.

Here, we investigate the NXRs for five types of goods for the United States, Japan, Korea, and China. The five types of goods are capital goods (CAP), parts and components (PRT), processed goods (PCS), consumption goods (CON), and primary commodities (PRM). ${ }^{1}$ In order for the NXRs to be meaningful to investigate the

\footnotetext{
${ }^{1}$ The classifications of goods are as follows: CAP (BEC 41,521), PRT (42,53), PCS (BEC 121,22,32), CON (BEC 112,122,51,522,61,62,63), PRM (BEC 111,21,31).
} 


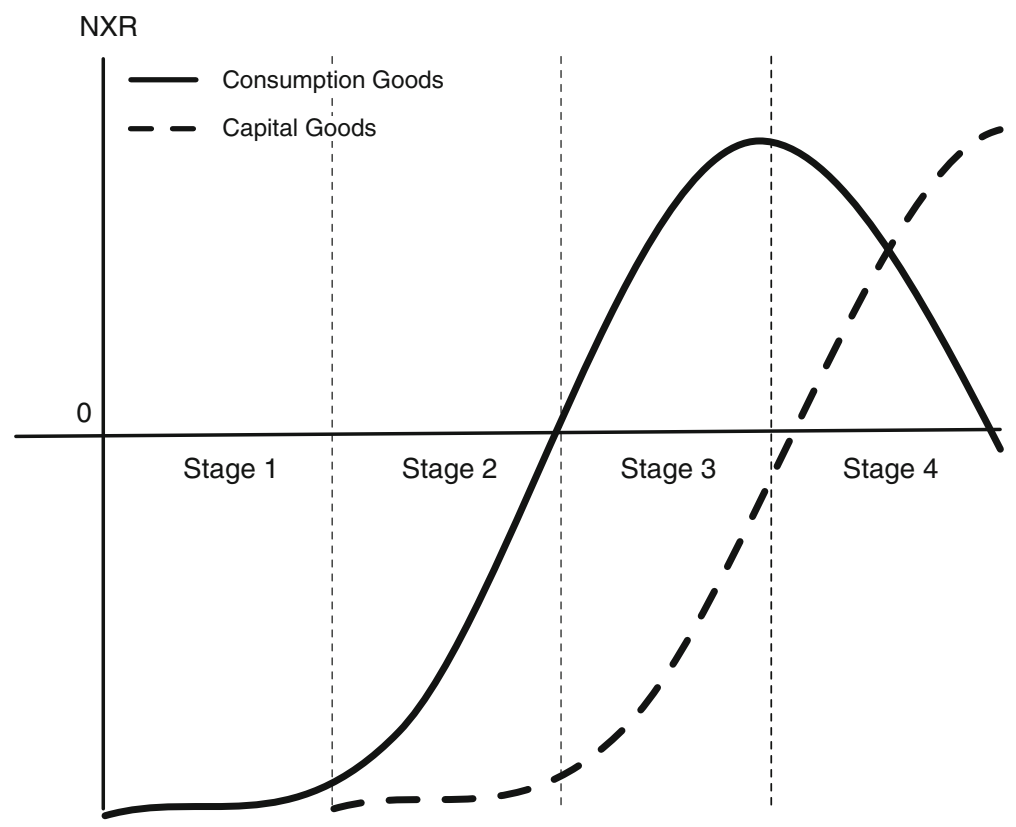

Fig. 3.4 FGP Depicted by the net export ratio. Source Constructed by the author

trade structure, the types of goods should be selected to represent different degrees of factor intensity. We suppose the order of the goods along the lower-to-higher capital/labor ratio is $\mathrm{CON}<\mathrm{PCS}<\mathrm{PRT}<\mathrm{CAP}$, while PRM includes either resourceor land-intensive goods.

We suppose that the United States is the most advanced economy among these four countries, followed by Japan, Korea, and China, from higher to lower income levels. We would find that the United States has the most advanced trade structure (i.e., exporting capital-intensive goods while importing labor-intensive goods) if the FGP is applicable. For China, the rearmost country among the four nations, the FGP predicts that it exports more labor-intensive goods while it imports capital-intensive goods.

We also investigate the net factor income as a percentage of GDP. We suppose that if one country has reached the high-income stage and starts to deindustrialize its economy to become a service-oriented one, then that country starts exporting capital (i.e., starts outward FDI), which causes the later inflow of factor income back to the home country. Thus, the net factor income (NFI) is expected to be neutral to negative at a lower income level and positive at a higher level of income.

Figure 3.5 shows the NXRs for five types of goods and the net factor income, percent of GDP, for the United States, Japan, Korea, and China, from the 1960s to 2010. The United States was already a net importer of consumption goods in the 1960s. The NXRs for CAP and PRT were largely positive in the 1960s, but gradually 
decreased to the negative zone after the mid-1980s. On the other hand, the NFI became positive in the late 1960s and continues to be positive through the present. Thus, the United States was an advanced industrial country exporting capital-intensive goods in the 1960s, but gradually deindustrialized and became a service-oriented advanced economy in the mid-1980s.

Japan is a net exporter of almost all goods except for primary commodities in the 1960s and its highest NXR is for CON at that time. The NXR for CON had been decreasing since the mid-1980s, and is in the negative area after the 1990s. The NXRs for CAP and PRT are always positive; the NFI apparently became positive after the 1980 s and has been increasing rapidly in the 2000s. Thus, Japan has successfully upgraded its export structure from labor-intensive goods to capital-intensive goods in the 1970 s and the 1980 s, and was transformed into a service-oriented economy after the 2000s.

South Korea is always a net exporter of CON, but the peak was in the 1970s and the 1980s. The NXRs for CAP and PRT were both negative during the 1960s and the 1970s, but after the 1990s, the NXRs for both goods became positive. The NFI also became positive in the 2010s. Thus, South Korea was assembling imported parts and utilizing imported capital goods and parts to produce consumption goods for export during the 1960s and the 1970s, but successfully upgraded its exports to more sophisticated capital-intensive goods after the 1990s. It has now has become an advanced industrialized economy.

For China, data is only available after the 1980s. The transformation of its export structure was very rapid. China's NXR for CON has been very high since the late 1980 s through the present, although it declined slightly in the latter half of the 2000s. The NXR for CAP has increased steadily since the 1980s and became positive after 2000; the NXR for PRT also become positive after the mid-2000s. Thus, China became a successful exporter of consumption goods after the 1990s and upgraded its export structure to be a net exporter of capital goods and parts in the 2000s.

The comparison of NXRs by type of goods for these four countries reveals that there is a clear order in the changing NXRs of each good in each country, according to income level. First, a country becomes a net exporter of consumption goods while importing capital goods and parts. Then, a country becomes a net exporter of capital goods and parts while reducing net exports in consumption goods and, subsequently, becomes a net importer of consumption goods. Finally, a country's net factor income, mainly the income from accumulated FDI overseas, becomes positive, rather than exporting goods. This process of industrial upgrading, which is very much compatible with the four stages of FGP proposed by Akamatsu $(1935,1962)$, is a logical consequence of the process.

Kojima (2000) posits that FDI distributed in East Asia is mainly so-called protrade-oriented FDI (PROT-FDI), which is behind the FGP of economic development in East Asia. PROT-FDI is the FDI distributed by an industry of a country that has a relatively low comparative advantage in that industry, to a country with a greater comparative advantage in areas that are relevant to that industry. The host country can 

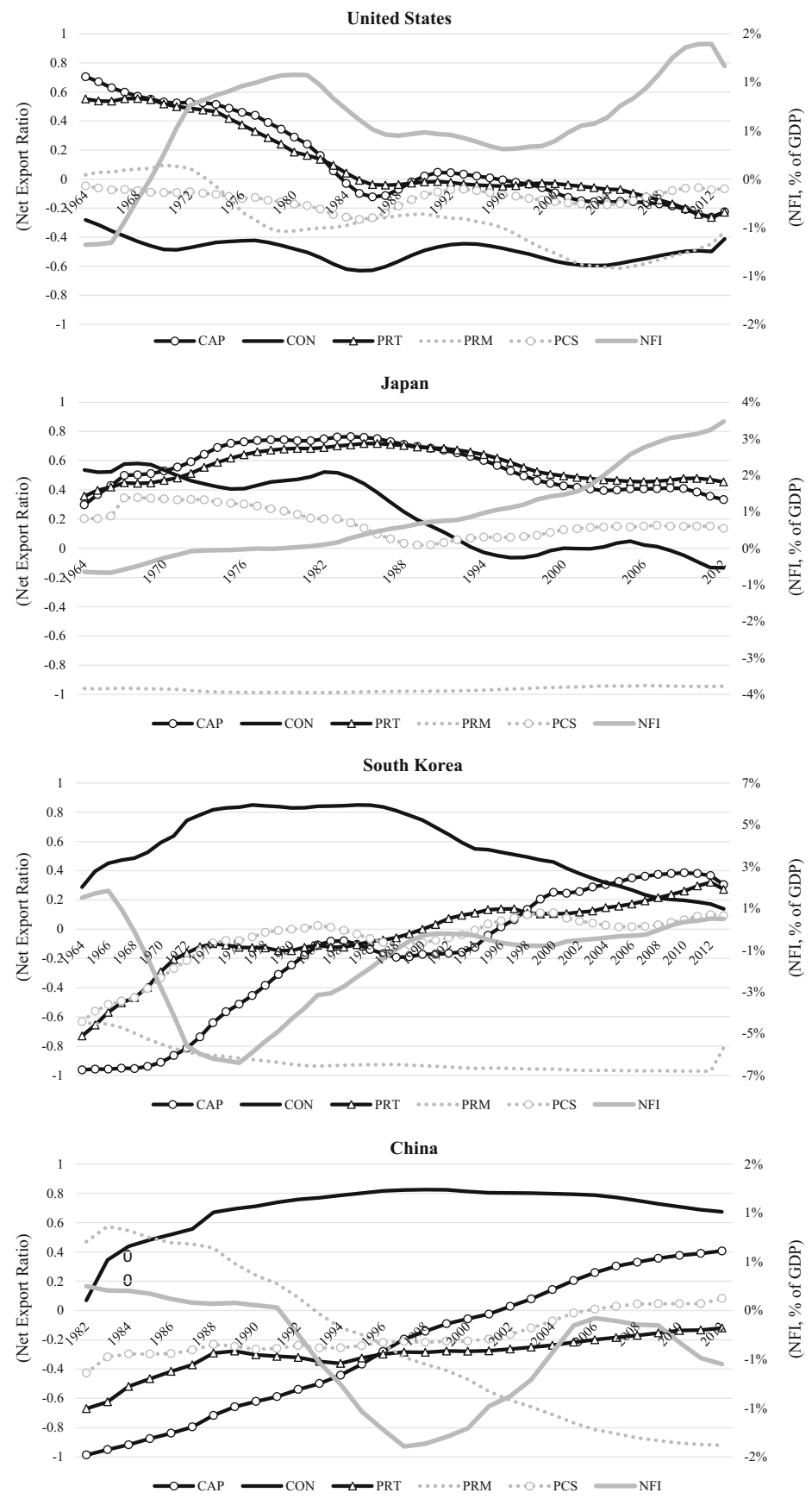

Fig. 3.5 Net export ratio by type of goods, 1964-2012 (5-year average). Source Calculated by the author based on UN COMTRADE database 
enhance the productivity of the FDI industry and increase its exports while the home country can enhance the productivity of industries therein that exhibit comparative advantages through the FDI.

\subsection{Export Structure of the ASEAN-4}

In this section, we investigate the NXRs of five types of goods for the ASEAN-4 countries, namely Malaysia, Thailand, Indonesia, and the Philippines. If the historical pattern of changing NXRs is very similar to that of Japan and South Korea, then the county is regarded as being on track for the FGP, successfully upgrading its export structure. Otherwise, if it does not follow the pattern, it may be that the country is failing in industrial upgrading and is on the verge of the MIT.

\subsubsection{Malaysia}

Figure 3.6 shows the historical changes in the NXRs for the four Southeast Asian countries. In the 1960s, Malaysia was a net exporter of PRM and PCS, while a net importer of CAP and PRT, and its NFI is negative. Thus, the export structure of Malaysia in the 1960s is typical for exporters of primary commodities. During the 1970s, the structure of the NXRs demonstrated little change except for increasing NXR for PRT. This observation corresponds with the early success of the free trade zones (FTZs) in Penang, where mainly U.S. semiconductor manufacturers started to export assembled semiconductors back to America.

During the 1980s, the structure of NXRs completely changed is a single decade. The NXR for CON became positive and the NXR for CAP also began to increase. On the other hand, NFI decreased, reflecting that the MNCs were the major players in exporting consumption goods and they repatriated their profit from the exports. Thus, Malaysia became a net exporter of consumption goods, aided by the MNCs attracted to the FTZs in Malaysia.

In the 1990s, Malaysia appeared to successfully upgrade its export structure, maintaining the momentum of the early success of the export-oriented industrialization since the mid-1980s. However, in the 2000s, there seemed to have been an anxious move in the NXRs. While the NXR for CON peaked, the NXRs for CAP and PRT did not increase. We cannot yet say whether Malaysia has failed in industrial upgrading, but it appears to have been stagnant since the 2000s. 

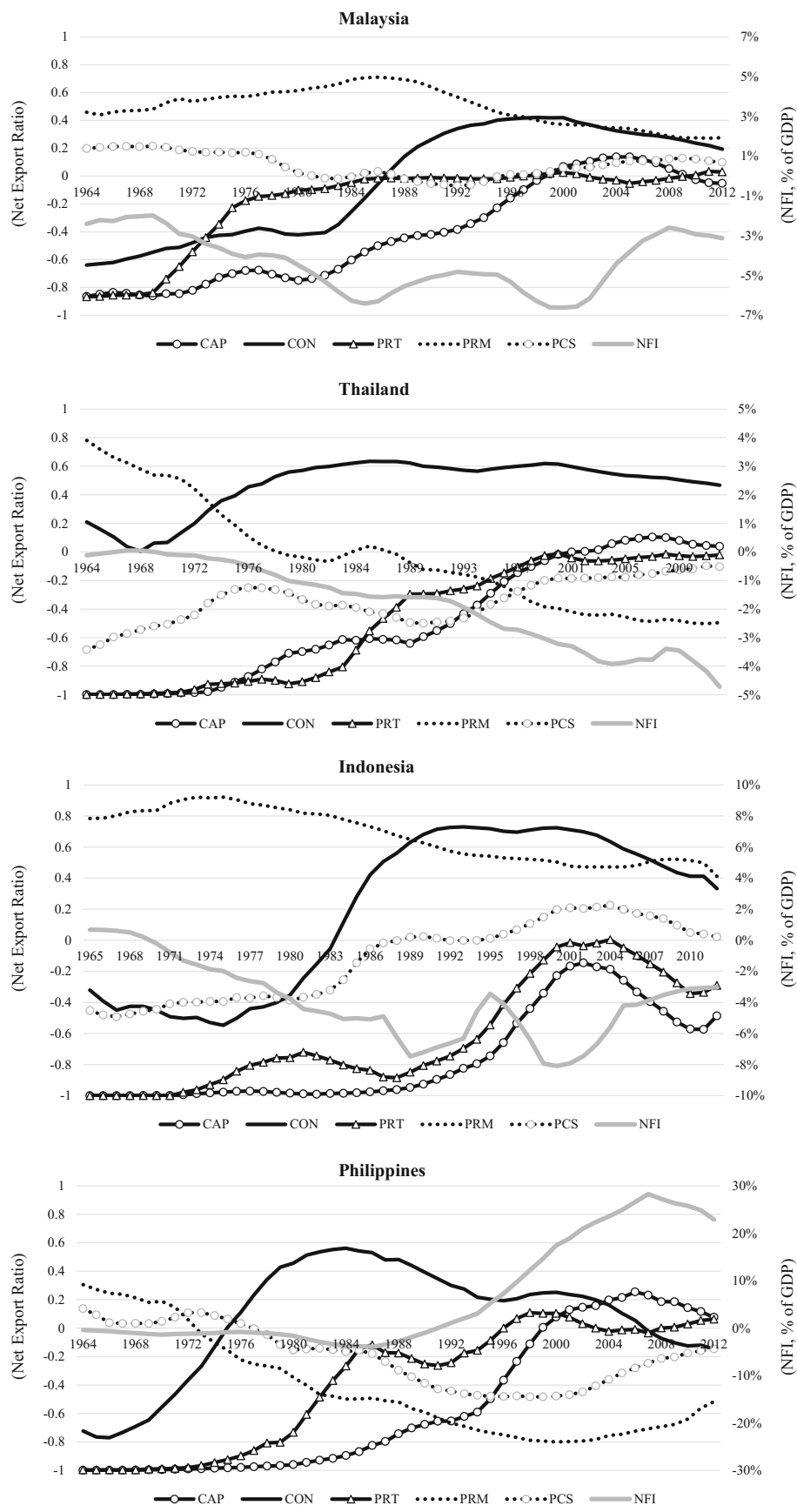

Fig. 3.6 Net export ratio by type of goods, 1964-2012 (5-year average). Source Calculated by the author based on UN COMTRADE database 


\subsubsection{Thailand}

According to the panel of Thailand of Fig. 3.6, Thailand was a net exporter of PRM while a net importer of CAP, PRT, and PCS in the 1960s. In the 1970s, the NXR for CON increased while the NXR for PRM became negative during the 1980s. Thus, Thailand transformed itself from an agricultural economy to an industrialized economy in the latter half of the 1970s and the 1980s, from the viewpoint of export structure.

In the latter half of the 1980s and the 1990s, the NXRs for PRT and CAP have started increasing and switched from neutral to positive in the 2000s and after. It seems that Thailand upgraded its industrial structure to that of a middle-level industrial economy. However, the pace of increase in the NXRs for CAP and PRT is not as fast as expected from the pace in the 1990s.

Another thing that shows Thailand's struggle to upgrade its industrial structure is a steadily decreasing NFI. This is caused by the remittance of MNCs and foreign labor in Thailand to their home countries. Thus, it will take quite some time for Thailand to be a service-oriented economy.

\subsubsection{Indonesia}

The panel of Indonesia of Fig. 3.6 shows that Indonesia has long been a net exporter of PRM. Until the mid-1980s, Indonesia was a net importer of all other goods except for PRM. Thus, Indonesia was a typical commodity-exporting economy before the mid-1980s.

In the mid-1980s, Indonesia became a net exporter of CON. The NXRs for CAP and PRT increased through the 1990s to almost a neutral area. Thus, in the late 1990s, Indonesia seems to be successfully upgrading to a middle-level industrial country.

However, the NXR for CON started to decrease in the 2000s. The NXRs for CAP and PRT also began to decrease in the mid-2000s. Indonesia seemed to be commencing the deindustrialization process in the 2000s from the trade structure viewpoint. The NXRs for PRM slightly increased in the latter 2000s because of increasing prices in various primary commodities.

\subsubsection{The Philippines}

The panel of the Philippines of Fig. 3.6 shows the historical changes in the NXRs for the Philippines. In the 1960s, the Philippines was a net exporter of PRM and PCS and a net importer of CON, CAP, and PRT. However, the NXR for CON started to increase in the late 1960s and became positive in the latter half of the 1970s. Throughout the 1970s, the GDP per capita in the Philippines was almost the same level as that of 
Thailand. The NXR for PRT increased to a neutral area in the mid-1980s. Thus, industrialization seems to be successful in the Philippines until the mid-1980s.

The NXR for CON started to decrease since the mid-1980s and became negative in 2008 and after. The NXR for PRT became positive in the latter half of the 1990s, but did not increase since then. The NXR for capital goods started to increase in the mid-1990s and became positive in the 1990s, but decreased since the mid-2000s. Thus, the Philippines seemed to be starting deindustrialization, although the per capita income is still in the lower middle-income stage.

One notable characteristic of the Philippines is a hugely positive NFI, almost $30 \%$ of GDP at its peak. The Philippines is one of the highest earners of net factor income as a percentage of GDP in the world. This is apparently caused by the remittance of overseas Philippines workers, not by the remittance of Philippines MNCs operating overseas.

\subsection{Why Has Industrial Upgrading in the ASEAN-4 Stalled?}

In this section, we discuss why the industrial upgrading in the ASEAN-4 countries has seemingly stalled after the year 2000, while the industrial upgrading in South Korea and China appeared smoother. There are several possible factors behind the seemingly stalled industrial upgrading in the ASEAN-4 and here we investigate two factors: (1) the "resource curse" hypothesis and (2) the lack of homegrown MNCs in the manufacturing sector.

\subsubsection{Resource Curse Hypothesis}

The first possible factor behind the stalled industrial upgrading in the ASEAN-4 countries is the booming primary commodities during the 2000s. The Brent crude oil price was around $\$ 13 /$ barrel in 1998 , but it rose to $\$ 50 /$ barrel in 2005 and $\$ 100 /$ barrel in 2008. This commodity boom transfers investment away from the manufacturing sector to the commodity sector, especially in Malaysia and Indonesia, the net exporters of primary commodities.

In Malaysia, five major export commodities (e.g., crude oil, natural gas, palm oil, rubber, and $\log$ /timber) have less than $10 \%$ share of total export in 1998, but recovered to almost one fourth of the total exports in 2013. This composition affects the business portfolio of domestic companies in Malaysia. For instance, Sapura Group, one of the limited numbers of Bumiputera companies that has competitiveness in the manufacturing sector, was a supplier of telecommunication equipment in the 1980s and expanded to the IT sector in the 1990s. However, after the 2000s, Sapura Group invested heavily in the oil and gas sector. Now its main business portfolio is Sapura 


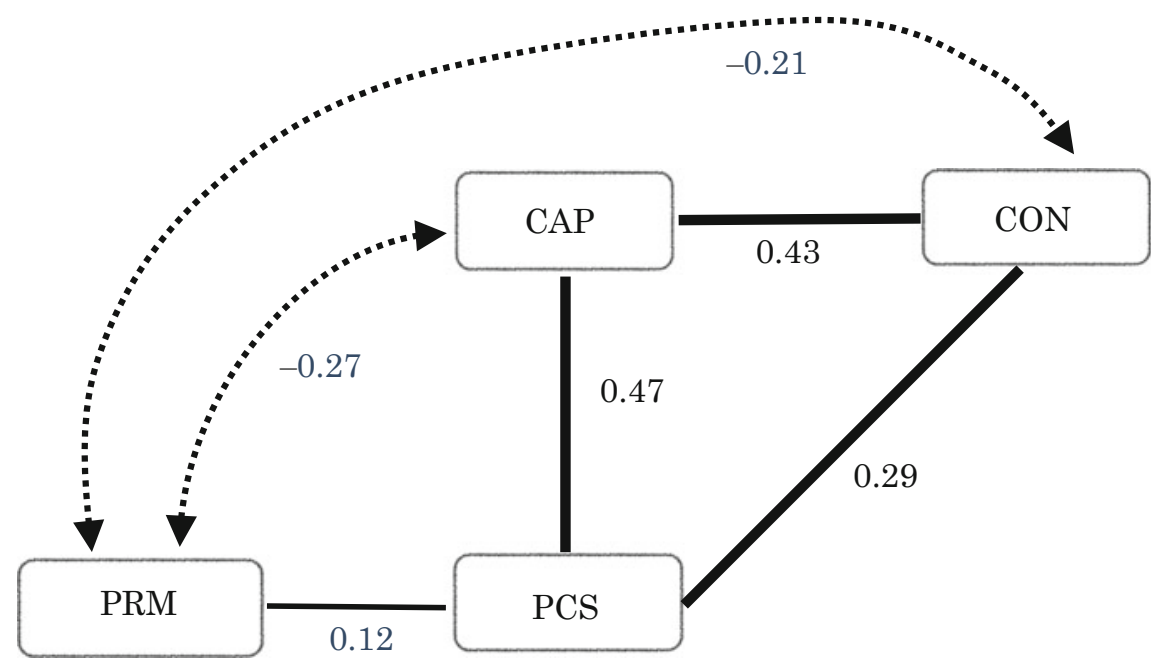

Fig. 3.7 Correlations among NXRs for four types of goods (annual average for 1960-2015). Source Calculated by the author based on UN COMTRADE database

Energy Bhd., a multinational oil and gas service provider operating in more than 20 countries.

However, serving as a net exporter of primary commodities is not necessarily a good way for a country to upgrade its industry. Figure 3.7 shows the correlations between the NXRs of four types of goods. ${ }^{2}$ The NXRs of CAP, CON, and PCS have positive correlations with each other. Since CAP is more sophisticated than CON, industrial upgrading through the backward linkage from CON to CAP is a likely path. In contrast, the relationships between PRM and CON and between PRM and CAP are both negative. This indicates that it is difficult for a country to be a net exporter of both PRM and CON or both PRM and CAP. Thus, a net exporter of primary commodities is less likely to be a net exporter of consumption goods and will not experience an industrial upgrading through a backward linkage from consumption goods to capital goods.

Indeed, there is an augment to the so-called "resource curse" that insists the abundance of natural resources paradoxically hinders the economic development of a country. Factors behind this curse include the volatility of prices, crowding out of the manufacturing sector, appreciation of currency leading to Dutch disease, and other factors (Frankel 2010).

Kumagai (2015) shows analyses of the export structure of "trapped" and "nontrapped" samples during 1960-2010 for 198 countries and conducted an empirical analysis of the relationship between income level and NXRs for different types of goods. The author found that industrial upgrading appears to occur exactly as depicted

${ }^{2}$ CAP and PRT have a high correlation of 0.89 , and the correlations with other goods is almost similar. Thus, here we only show CAP in Fig. 3.7. 
by the flying geese model for non-trapped countries, while trapped countries tend to depend on the exportation of primary commodities, regardless of income level.

For the ASEAN-4 countries, the trade pattern is differs from the pattern of "trapped" counties, but it is undeniable that the trade structure was affected by the commodity boom in the 2000s, especially for Malaysia and Indonesia. Thus, these two countries are likely to be "mildly cursed" by their richness in natural resource endowment.

One thing that should be noted in relation to the resource curse is the peculiar export structure of the Philippines. The Philippines started losing competitiveness in consumption goods as early as the 1980s, and its competitiveness in parts and capital goods peaked at the end of the 1990s and the mid-2000s, respectively. This seemingly "upgraded" and now deindustrializing trade structure of the Philippines is very likely to be a consequence of the huge amounts of remittance coming into the country from overseas Philippines workers. The net factor income for the country, which mainly consists of remittance from these workers, amounts to almost $30 \%$ of the GDP at its peak. This, one of the world's largest remittances as a percentage of GDP, makes the Philippines a quasi-exporter of labor services to the world, causing the trade structure to behave just like a deindustrializing advanced country that receives a large remittance from its overseas FDI stocks.

\subsubsection{Lack of Homegrown MNCs in the Manufacturing Sector}

The second possible factor that may cause the industrial upgrading in the ASEAN-4 countries to become stagnant is the lack of homegrown MNCs in the manufacturing sector. This is obvious when compared to Japan, South Korea, and China, which are countries with multiple MNCs in various manufacturing sectors, such as automotive, electrical and electronics (E\&E), shipbuilding, and the chemical industry. On the 2017 Forbes Global 500 list by country, there are 51 companies from Japan, 15 from South Korea, and 106 from China, while only one company each from Malaysia, Thailand, and Indonesia and no companies from the Philippines. Although there are homegrown MNCs in the ASEAN-4 countries that have recently started aggressively investing overseas, these are mainly companies in the service sector or natural resources-based industries.

Why are homegrown MNCs important for industrial upgrading, especially from the viewpoint of the trade structure? The reason lies in the difference between consumption goods and parts and capital goods. The export of capital goods and parts needs production networks, while the exports of consumption goods do not necessarily require them. To be a net exporter of consumption goods, the existence of homegrown retailers in foreign markets is not necessarily needed. On the other hand, selling parts and capital goods directly to foreign markets is relatively difficult. For example, if a manufacturer in the home country that buys parts and components from 
domestic suppliers wants to invest abroad and starts production in a host country, the firm will procure parts and capital goods from the home country, especially in the early stage of operation overseas. Thus, FDI of manufacturing MNCs makes it easier for a country to be a net exporter of parts and capital goods.

The comparison of South Korea, Thailand, and Malaysia in the automotive sector is illustrative. South Korea became a net exporter of passenger cars at the end of the 1970s. Its homegrown automakers, such as Hyundai Motors and Kia Motors, began overseas production during the 1990s, then the net exports of automotive parts become positive soon after. South Korea is a successful case of industrial upgrading from an exporter of passenger cars to the net exporter of both passenger cars and automotive parts.

Thailand has followed a different path of industrial development in the automotive sector. Thailand opened up its home market to foreign automotive MNCs, such as Toyota, Honda, and Nissan, in the 1990s, and started to export assembled cars largely from Thailand after the Asian financial crisis in 1997-1998. The NXR of passenger cars for Thailand was recently around $0.7-0.8$. On the other hand, the NXR of automotive parts became positive since the mid-2000s, and it is still around $0.1-0.2$. This result is because the automotive MNCs operating in Thailand export some parts, but at the same time, import other parts from their home country and other ASEAN countries under the ASEAN Free Trade Area (AFTA). Thailand is producing automotive parts competitively in the international production networks for MNCs, but is not a main source of parts and capital goods for automotive MNCs that have operations in their own home countries.

In the case of Malaysia, the NXRs of passenger cars and automotive parts are both negative. This is an obvious weakness in Malaysia's export structure as a middleincome economy and a contributing reason why Malaysia's NXRs for CAP, PRT, and CON are lower than expected after the 2000s.

Malaysia's weak competitiveness in the automotive sector is not caused by its narrow car market. With approximately 600,000 cars sold per year, Malaysia has the highest population/car sales ratio among ASEAN countries. Surprisingly, it had the largest passenger car sales among the ASEAN-4 countries until 2010. It is obvious that the early success of Proton (Perusahaan Otomobil Nasional Bhd.), a national car company, is a factor that led to the later failure of the automotive industry in Malaysia. Proton was established as a joint venture between Heavy Industries Corporation of Malaysia Bhd. (HICOM) and Mitsubishi Motors and Mitsubishi Corp. in 1983. For the first few years, Proton suffered stagnant domestic demand after the economic slowdown in 1985 and 1986, but then its production and sales steadily increased, supported by various incentives from the Malaysian government (Hasan and Sundaram 2007, pp. 170-72).

Proton is not a completely failed company. Conversely, it is very successful in the Malaysian market, having more than a $70 \%$ share of the passenger car market in the latter half of the 1990s. Although its early production was the rebranded Mitsubishi Mirage as the Proton Saga, its advancing R\&D capacity allowed it to develop its first original car from scratch, the Proton Waja, in 2000. Proton bought British sports car 
maker Lotus in 1996, and subsequently succeeded in developing its own $1600 \mathrm{cc}$ engine, called the CamPro, with Lotus in 2000 and has deployed it since 2004.

Still, Malaysia needed to extend the start date of AFTA in the automotive sector from January 2003 to January 2005. This extension shows a lack of competitiveness of the Proton, even within the ASEAN markets. Indeed, the strength of national carmakers in the Malaysian market emanates from vehicles' approximately $30 \%$ lower price, supported mainly by the exemption from or reduction of excise taxes. After AFTA, the Proton lost its position in the Malaysian market. In 2006, Proton gave up the position of the top car seller in Malaysia to Perodua (Perusahaan Otomobil Kedua Sdn. Bhd.), the second national car company. Now, Perodua produces 200,000 units a year while Proton's production is less than 100,000.

Proton cannot be a part of the ASEAN production networks in the automotive industry, because (1) Proton is not a MNC, thus the absence of overseas production facilities make it impossible to mutually export completely-built units or automotive parts under AFTA or the preceding Brand to Brand Complementation/ASEAN Industrial Cooperation (BBC/AICO) scheme. Further, (2), there are both explicit and implicit obligations to support local vendors, mainly Bumiputera firms, making it difficult to procure cost competitive parts from other countries. On the other hand, Perodua, virtually an affiliate of Daihatsu, Japan, from the viewpoint of its production networks, can be more competitive under AFTA than Proton.

\subsubsection{Two Alternative Approaches to Industrialization}

The Malaysian government under the Mahathir administration chose to set up Proton, a national car maker, to develop a homegrown automotive company with self-reliant technology. Thus, Malaysia took the same strategy as South Korea in the automotive sector. Unfortunately, Malaysia was not as successful. In Thailand, the automotive industry succeeded as a regional production hub for MNCs in the early 1990s by opening up its market without a national car project. However, it is not a big net exporter of automotive parts so far because Thailand is just one of the many countries in the production networks of the world's automotive MNCs.

The policy to develop home companies with their own technology has longlasting competitiveness in an industry, such as the Taiwanese E\&E sector, or the South Korean automotive sector, but such a policy is not always successful. Once failed, the cost of being excluded from the regional production networks of MNCs is very high.

The failure of Proton was mainly caused by the lack of competitiveness in foreign markets. Proton has a "given" home market through the preferential treatment from the government that makes it possible for Proton to sell its cars 30\% cheaper than non-national carmakers. The situation is different from that of the Taiwanese E\&E and South Korean automotive companies, who exported their products to overseas markets in the early stage of development, and were forced to compete with MNCs from other countries. 
The other strategy, inviting FDI for exports seems to be a more secure choice for a developing country. The FDI brings not only capital, but also technology and market access to the host countries, and ensures their inclusion in regional production networks. This strategy seems to be a short cut for a developing county to industrialization; however, there are costs in becoming dependent on foreign firms and foreign technology. As shown in the analysis above, industrial upgrading in manufacturing parts and capital goods is likely to be limited in FDI because the host county is just one of the many countries that MNCs include in their production networks.

Thus, the choice between "deep" industrialization consisting of homegrown companies with their own technology and "shallow" industrialization by inviting FDI is critical to determining the path for a developing country to industrialize and upgrade its economy. There is no single right choice between the two strategies to fit every country, but governments must be aware and consider the advantages and disadvantages of each strategy.

\subsection{Conclusion}

This paper investigated the "fear" of the MIT for the ASEAN-4 countries, from the viewpoint of trade structure using NXRs. The historical changes in the NXRs for different type of goods revealed that the ASEAN-4 countries had long been following the FGP after Japan and Asia NIEs, but diverged from similar paths of industrial upgrading after year 2000.

There are two possible factors that have caused the stagnant industrial upgrading in the ASEAN-4 countries. One possible factor is known as the "resource curse." After recovering from the recession caused by the Asian financial crisis in 1997-1998, resource-based industries in the ASEAN-4 countries, especially in Indonesia and Malaysia, enjoyed booming prices of primary commodities during the 2000s. This boom in primary commodities may have diverged investments from manufacturing to primary industries.

The second possible factor is the lack of homegrown MNCs in the manufacturing sector. In the manufacturing sector, the ASEAN-4 countries have fewer developed MNCs and are much more dependent on foreign direct investment than Japan, South Korea, and China, who all have homegrown competitive MNCs in the manufacturing sector. This lack of homegrown MNCs makes it difficult for the ASEAN-4 countries to export parts and components to overseas MNCs and take advantage of lower wage rates for the assembly process in other countries.

The policy to foster home companies with their own technology will bring longlasting competitiveness in an industry, but such a policy is not always successful. Once failed, the cost to be excluded from the regional production networks is very high. Therefore, there is a choice between "shallow" industrialization, depending on FDI and MNCs, and "deep" industrialization by home companies with their own technology. The former policy may help a country to industrialize quickly, but 
cannot help it be a leading goose. The latter policy has a higher return but high risks. Therefore, governments must carefully consider the potential and hazards of each strategy.

\section{References}

Aiyar, Shekhar, Romain Duval, Damien Puy, Yiqun Wu, and Longmei Zhang. 2013. Growth Slowdowns and the Middle-Income Trap. IMF Working Paper WP/13/71.

Akamatsu, Kaname. 1935. Waga kuni yomo kogyohin no boeki susei. [Trade Trend of Japan's Wool Industrial Goods]. Shogyo Keizai Ronso 13: 129-212.

Akamatsu, Kaname. 1962. Historical Pattern of Economic Growth in Developing Countries. The Developing Economies 1: 3-25.

Deardorff, Alan V. 1982. The General Validity of the Heckscher-Ohlin Theorem. The American Economic Review 72 (4): 683-694.

Dowlinga, Malcolm, and Chia Tien Cheang. 2000. Shifting Comparative Advantage in Asia: New Tests of the 'Flying Geese' Model. Journal of Asian Economics 11 (4): 443-463.

Eichengreen, Barry, Donghyun Park, and Kwanho Shin. 2012. When Fast-Growing Economies Slow Down: International Evidence and Implications for China. Asian Economic Papers 11 (1): 42-87.

Felipe, Jesus. 2012. Tracking the Middle-Income Trap: What is It, Who is in It, and Why? Part 1. ADB Economic Working Paper Series No. 306.

Frankel, Jeffrey A. 2010. The Natural Resource Curse: A Survey. National Bureau of Economic Research (NBER) Working Paper 15836.

Gill, Indermit, and Homi Kharas. 2007. An East Asian Renaissance: Ideas for Economic Growth. Washington DC: World Bank Publications.

Ginzburg, Andrea, and Annamaria Simonazzi. 2005. Patterns of Industrialization and the Flying Geese Model: The Case of Electronics in East Asia. Journal of Asian Economics 15 (6): 1051-1078.

Hasan, Hasli, and Jomo Kwame Sundaram. 2007. Rent-Seeking and Industrial Policy in Malaysia. In Malaysian Industrial Policy, ed. K.S. Jomo, 157-178. Singapore: NUS Press.

Kohli, Harinder S., Ashok Sharma, and Anil Sood (eds.). 2011. Asia 2050: Realizing the Asian Century. New Delhi: SAGE Publications.

Kojima, Kiyoshi. 1960. Capital Accumulation and the Course of Industrialisation, with Special Reference to Japan. The Economic Journal 70: 757-768.

Kojima, Kiyoshi. 2000. The 'Flying Geese' Model of Asian Economic Development: Origin, Theoretical Extensions, and Regional Policy Implications. Journal of Asian Economics 11: 375-401.

Kumagai, Satoru. 2015. The Middle-Income Trap from the Viewpoint of Trade Structures: Are the Geese Trapped or Still Flying? Journal of International Commerce, Economics and Policy 6 (03): 1550017.

Ohno, Kenichi. 2009. Avoiding the Middle Income Trap: Renovating Industrial Policy Formulation in Vietnam. ASEAN Economic Bulletin 26: 25-43.

Tran, Van Tho. 2013. The Middle-Income Trap: Issues for Members of the Association of Southeast Asian Nations. ADBI Working Paper Series No. 421.

World Bank. 1993. The East Asian Miracle: Economic Growth and Public Policy. London: Oxford University Press.

Yusuf, Shahid, and Kaoru Nabeshima. 2009. Tiger Economies under Threat: A Comparative Analysis of Malaysia's Industrial Prospects and Policy Options. Washington DC: World Bank Publications. 
Open Access This chapter is licensed under the terms of the Creative Commons AttributionNonCommercial-NoDerivatives 4.0 International License (http://creativecommons.org/licenses/bync-nd/4.0/), which permits any noncommercial use, sharing, distribution and reproduction in any medium or format, as long as you give appropriate credit to the original author(s) and the source, provide a link to the Creative Commons license and indicate if you modified the licensed material. You do not have permission under this license to share adapted material derived from this chapter or parts of it.

The images or other third party material in this chapter are included in the chapter's Creative Commons license, unless indicated otherwise in a credit line to the material. If material is not included in the chapter's Creative Commons license and your intended use is not permitted by statutory regulation or exceeds the permitted use, you will need to obtain permission directly from the copyright holder.

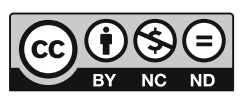

